\title{
A TÁMOGATOTT FELIDÉZÉS MÓDSZERE ÉS ALKALMAZÁSA A KUTATÁSBAN
}

\section{ÚJVÁRINÉ HANDó MELINdA}

\author{
handomelinda@freemail.hu
}

\begin{abstract}
Tanulmányunk célja a támogatott felidézés módszerének és sokoldalú alkalmazásának bemutatása egy konkrét kutatáson, nevezetesen a roma és nem roma tanulók iskolai környezetben zajló társas kapcsolatának mélyreható empirikus vizsgálatán keresztül. Két éves kutatásunk célja az volt, hogy több aspektusból tárjuk fel a roma és nem roma gyerekek közötti interakciókat, valamint a mögöttük meghúzódó gondolatokat, attitüdöket. Jelen tanulmányunkban a támogatott felidézés módszerének átfogó bemutatása mellett törekszünk arra, hogy konkrét kutatásunkon keresztül gyakorlati tanácsokkal is szolgáljunk olvasóink számára, ezzel is buzdítva kutató társainkat a módszer alkalmazására.
\end{abstract}

\section{A támogatott felidézés módszerének bemutatása}

Mielőtt a kutatásunk során szerzett tapasztalataink bemutatására rátérnénk, fontosnak tartjuk, hogy magával a módszerrel és annak müködésével megismertessük a tisztelt olvasót, elsődlegesen Szivák Judit (Szivák, 2002) munkájára támaszkodva.

A támogatott felidézés módszere leginkább az interjú technikával és a mikrotanítással mutat hasonlóságot, azonban mégis különbözik ezektől. A módszer sokoldalúan használható a kutatásban, hiszen ,,alkalmas egyének, csoportok ismeretrendszerének, vélekedéseinek, attitüdjeinek, élményeinek feltárásával összefüggések, szabályszerüségek bemutatására”. (Szivák, 2002. 36. o.)

Támogatott felidézéssel az oktatási folyamat szinte minden résztvevőjének gondolkodási folyamatai feltárhatóak, legyen szó akár óvodásról, óvónőről, tanulóról, pedagógusról, szülőről vagy hallgatóról. Azonban a szakirodalomban többen is felhívják a figyelmet arra, hogy a támogatott felidézés mindig csak más módszerrel - például interjúval - való alkalmazása során szolgáltat releváns információkat, mivel önmagában alkalmazva nem biztos, hogy azt és úgy méri, amit és ahogyan kellene. Éppen ezért vizsgálatunkat szociometriai kérdőív, valamint az iskolaigazgatókkal készült mélyinterjú egészítette ki, melynek során holisztikusabb képet kaphattunk az iskoláról, a tanulókról, a szülőkről, a tanár-diák viszonyról, valamint magáról a településről. Emellett a résztvevő-megfigyelő módszer segítségével bepillantást nyertünk az egyik település cigány közösségének életébe is, feltárva a szükebb társadalomban meghúzódó feszültségeket, előítéleteket és konfliktusokat valamint az ezek mögött megbújó okokat. 


\section{A támogatott felidézés jellemző alkalmazási területei}

A támogatott felidézés legjellemzőbb alkalmazási területei egyrészt a tanulási folyamatra irányuló vizsgálatok, melyek a diákok tanulás közben lezajló gondolkodási folyamatait állítják középpontba. Ezen kutatásokban az ismeretelsajátítás, a tanulási technikák megismerése, valamint fejlesztése a fő cél. A módszer másik jellemző alkalmazási területe pedig a tanári gondolkodás, döntéshozatal vizsgálata. E két fö alkalmazási terület mellett természetesen - mint ahogyan azt a szakirodalmi háttér áttekintésekor is látni fogjuk -, sok egyéb témában is jól alkalmazható a támogatott felidézés.

\section{A módszer alkalmazásának bemutatása a szakirodalmi háttér áttekintésével}

Annak érdekében, hogy illusztrálni tudjuk a támogatott felidézés kutatásban való felhasználásának sokszínűségét, áttekintjük az általunk elérhető és legfontosabbnak tartott kutatásokat kronológiai sorrendben, törekedve a módszer sokoldalúságának bemutatására.

Korábban kérdőívek és interjúk segítségével próbálták feltárni a tanár tevékenységét irányító célokat, szándékokat, de ezek a vizsgálatok többnyire függetlenek voltak az osztálytermi történésektől. Bloom volt az első, aki a támogatott felidézés technika használatáról számolt be 1953-ban az Egyesült Államokban (O’Brien, 1993). Bloom (1954) szerint a tanárok képtelenek voltak arra, hogy hangosan gondolkodjanak, miközben az órát is vezetik, vagyis lehetetlen volt vizsgálni a tanárok gondolkodását, döntéseit tanítás közben. Ez volt az ún. 'think aloud' technika. Az osztálytermi interakciókat rögzíteni kellett, hogy a tanár képes legyen pontosan és teljes egészében felidézni, megfogalmazni gondolkodási eljárásait. Később Bloom (1954) „az előadások és a szemináriumok hanganyagát rögzítette és játszotta vissza egyetemi hallgatóknak azzal a céllal, hogy az egyetemisták kommentárjainak segítségével feltárja a gondolkodási-emlékezési folyamatokat e két eltérő tanulási szituációban." (idézi Szivák, 2002. 40. o.) A beszámolók tartalmát kategória rendszer segítségével elemezte, és ilyen módon a támogatott felidézés módszerével igazolni tudta, hogy a szeminárium jellegü szituációkban eredményesebb a tanulás és az emlékezés is.

Kagan és munkatársai (1967) a támogatott felidézés egy sajátos formáját alkalmazták, az ún. IPR-t (Interpersonal Process Recall). Szemináriumvezetők óráit rögzítették, és a felvétel visszajátszása során kérdésekkel irányították a beszámolójukat. „A kísérlet célja az volt, hogy növelje a szemináriumvezetők tudatosságát az órai interakciók során." (idézi Szivák, 2002. 40. o.)

Magyarországon 1983-84 folyamán Falus Iván, Kotschy Beáta és Szokolszky Ágnes tett kísérletet a támogatott felidézés módszerének alkalmazására (Falus, 1985; Kotschy, 1985; Szokolszky, 1985). Kutatásukban három fő kérdésre keresték a választ: 1. Milyen szempontokat vesz figyelembe a pedagógus a tanítási óra meg- 
tervezésekor, mely esetekben tér el eredeti tervétől? 2. A tanítási óra menetében megfigyelhető cselekvései milyen mértékben tekinthetők tudatos döntések eredményének, illetve mennyire automatizáltak; a tudatos döntéseknek milyen komponensei vannak? 3. A tanárnak az osztályban és az egyes tanulókhoz füződő kapcsolata hogyan befolyásolja a tevékenységét, milyen mértékben képes észlelni a pedagógus az egyes tanulók órai viselkedését, érzéseit, gondolatait? A fenti kérdések megválaszolására összetett metodikát alkalmaztak, melynek központi eleme a támogatott felidézés volt. A vizsgálat kezdetén előzetes interjút készítettek a tanárral az osztályról, saját pedagógiai felfogásáról, illetve a tanítandó témáról. Ezt követően minden óra után kérdőívet töltettek ki a tanulókkal a tanórai részvételükre vonatkozóan. Minden óráról videofelvételt készítettek, miközben minden órán négy tanuló viselkedését figyelték meg részletesebben. Ezt követően kikérdezték a tanárt a megfigyelt gyerekekről. Majd következett minden rögzített óra elemzése a támogatott felidézés módszerével, melynek szakirodalomból ismert két változatát kombinálva alkalmazták. Azaz, elsőként a tanár észrevételeire voltak kíváncsiak, ha ilyenek nem voltak, akkor megállították a felvételt és kérdéseket tettek fel. Összesen hat tanórát rögzítettek 1983 decemberében. A kutatásban egy pedagógus oktatónevelö munkájának elemzésére kerülhetett sor a komplex metodika alkalmazása miatt, melyet a kérdésfeltevés összetettsége indokolt.

Clark és Peterson (1986) egy történelemóra négy pontján rögzített két-három perces részleteket, majd ezek visszajátszásakor a tanároknak válaszolniuk kellett olyan kérdésekre, hogy az adott pillanatban mit csináltak és miért, volt-e olyan reakciója a diákoknak, mely megváltoztatta a tervezett cselekvését stb. Egy másik kísérletükben a tanárok döntési folyamatainak három, feltételezett szintjét tanulmányozták a módszer segítségével. A kísérlet eredményei azt mutatták, hogy a tanárok a döntési szintek tudatos gyakorlásának következtében későbbi óráikon gyakrabban hoztak megalapozottabb döntéseket.

Westerman (1991) kezdő és gyakorlott pedagógusokat hasonlított össze a pedagógiai gondolkodás és döntéshozatal különbségeinek feltárása céljából. Három szintet vizsgált: a tervezési, a tanítási és a reflektív szintet. Az egyik csoportot öt, minimum öt éves tanítási gyakorlattal rendelkező pedagógus, a másikat pedig öt végzős egyetemista alkotta. A tervezési szinten strukturált elő interjúkat készítettek a tervezés alatt lezajlott döntéshozatali aktusokról. A tanítási szinten rögzítették a tanórákat, majd röviddel az órák után támogatott interjúkat készítettek. A tanárt arra kérték, hogy állitsa meg a szalagot minden olyan helyen, ahol úgy érzi, döntést hozott, és a lehetö legtömörebben fejtse ki, hogy mit mérlegelt abban a szituációban. A reflektív szinten a videofelvétel megtekintése után kérdések segítségével próbálták előhívni az utólagos értékeléseket és az óráról alkotott reflexióikat. Néhány hónappal a vizsgálatot követően minden vizsgált személynek lejátszották a felvett óráit hang nélkül, a tanárnak nem volt módja megállítani a szalagot, de folyamatosan kommentálnia kellett a látottakat. Tehát azt vizsgálták, hogy változott-e a pedagógus gondolkodása 
az eltelt idő alatt. Személyenként két tanórát vettek fel, így összesen 20 tanórát rögzítettek. Az eredmények azt mutatták, hogy jelentős különbség van a kezdő és a gyakorlott pedagógus gondolkodása és döntéshozatali tevékenysége között.

Bay és Tanis (1991) a veszélyeztetett gyermekek képességeiről való tanári gondolkodást kutatta. 28 tanár vett részt a vizsgálatban. Azt találták, hogy ,a pedagógusok hajlamosak feltételezni, hogy a szociálisan veszélyeztetett gyerekek kognitív képességei gyengébbek." (idézi Szivák, 2002. 52. o.)

A támogatott felidézés módszerével olyan kutatásokat is végeztek, melyek során a pedagógusokban élő előfeltevéseket, nézeteket vizsgálták. Powell (1992) azt kívánta bizonyítani, hogy a kezdő tanárok döntéshozatali akcióit, illetve a tanulókkal folytatott interakcióit ezen előfeltevések, előzetes elméletek határozzák meg. 17 hagyományos és 25 speciális pályakezdővel végezték el a vizsgálatot, melynek elején elméleti pedagógiai képzésben kellett részt venniük, majd pedig tíz órás terepgyakorlaton. A támogatott felidézés módszere mellett fogalomtérképeket is használtak, melyeket a hallgatók az elméleti képzés során készítettek el. A második héten tanítaniuk kellett tíz percben. Az óra megtervezésekor nem kérhettek segítséget senkitől. Az utólagos interjúban viszont meg kellett indokolniuk, hogy milyen tényezőket vettek figyelembe az óra megtervezésekor. Az órákról videofelvétel és támogatott felidézés készült. Az órák kritikus pontjait feljegyezték, és ezeket indokoltatták meg a hallgatókkal.

Moallem Mahnaz (1994) az osztály szociokulturális feltételeinek tanárra kifejtett hatását vizsgálta. Tíz tapasztalt tanár vett részt a vizsgálatban. Úgy találta, hogy „a csoport szociokulturális háttere nemcsak a tananyag kiválasztásában befolyásolta a tanárt, de az alkalmazott interakciók számában és minőségében is." (idézi Szivák, 2002. 52. o.)

Corrigan (1998) a tanár-diák interakciók mögött meghúzódó kulturális elöítéletek kutatásával foglalkozott. Négy tanárnő vett részt a vizsgálatban, akik közül kettő rendelkezett, kettő pedig nem rendelkezett információkkal a más kultúrákban élőkről. Megállapította, hogy „az eltérő kultúrákról kevesebb információval rendelkezők sokkal több elóítélettel rendelkeznek. A tanárok attribúciói a velük azonos kultúrából származó gyerekeknek kedveztek.” (idézi Szivák, 2002. 51. o.)

Sántha Kálmán (2004) a támogatott felidézés és a strukturálatlan kognitív térkép alkalmazásával vizsgálta a pedagógusok reflektív gondolkodását és nézeteit. A vizsgálatban öt gimnáziumi matematikatanár, köztük egy pályakezdő, egy-egy kilenc, tizenöt, tizenhét, valamint egy 25 éve pályán lévő pedagógus vett részt. A kutatás során a pedagógusok három-három óráját rögzítette, melyek felvétele ugyanabban a témában és osztályban történt. A felvétel során a fö szempontot a pedagógus tanóra közbeni cselekvése jelentette. A felvétel megtekintésének azt a módját választotta, hogy a felvételt mind a kutató, mind a tanár bármikor megállíthatta és kommentálhatta. A tanár szabadon asszociálhatott a témához, illetve az osztályhoz kapcsolódó élményei között, melynek eredményeként a beszélgetések jóval több időt vettek 
igénybe, mint maguk a tanórák. A támogatott felidézés mellett strukturálatlan fogalmi térképeket is alkalmazott a kutatás során. A vizsgálat során beigazolódott, hogy a két módszer együttes alkalmazása célravezető volt, hiszen több esetben támogatták, vagy éppen cáfolták egymás eredményeit, segítették az elemzést. A kutatás során végül arra az eredményre jutott, hogy a pedagógusok tevékenysége eröteljesen függ a pedagógiai tudásuktól, nézeteiktől és az adott pedagógiai szituációtól. Vagyis abból, ahogyan egy tanár a különböző helyzeteket értékeli és kezeli, nem következik, hogy egy másik tanár is hasonlóan fog cselekedni ugyanolyan helyzetben. Minden pedagógus „nézeteinek és pedagógiai tudásának differenciáltsága alapján reagál az adódó szituációkra, azaz meglévő rutinjának, kognitív sémáinak köszönhetően cselekszik." (Sántha, 2007. 239. o.)

A támogatott felidézés módszerét további kutatók is alkalmazták, de ezek ismertetésére most nem térek ki részben az előzőekben bemutatott hasonló megoldásaik, részben saját kutatásom szempontjából kevésbé releváns eredményeik, részben a terjedelmi korlátok miatt.

\section{A támogatott felidézés típusai a felvétel megtekintésének módja szerint}

A támogatott felidézés első szakaszában készült tanórai felvétel megtekintése és a kutatási alany beszámolójának irányítása többféle módon történhet. Az első módszer szerint a teljes felvétel végignézése után a kutatási alany, kérdések nélkül, szabadon számol be a tanóra alatti gondolatairól, döntéseiröl. A másik eljárás szerint a kutató irányítja a felidézést azáltal, hogy kiválaszt bizonyos részleteket, melyeknél a felvételt megállítja, majd kérdéseket tesz fel a kutatási alanynak. Végül a harmadik módszer szerint a tanóra felvételének folyamatos nézése közben a kutatási alany tetszése szerint választja ki azokat a pontokat, ahol véleménye szerint döntési, problémamegoldó helyzetben volt (Szivák, 2002).

A támogatott felidézés egyes típusainak előnyeit és hátrányait Szivák összefoglaló táblázata alapján mutatom be (lásd 1. táblázat).

1. táblázat: A támogatott felidézés előnyei és hátrányai

\begin{tabular}{|l|l|l|}
\hline \multicolumn{1}{|c|}{ Típus } & \multicolumn{1}{|c|}{ Elönye } & \multicolumn{1}{c|}{ Hátránya } \\
\hline $\begin{array}{c}\text { 1.’Teljes } \\
\text { végignézés” }\end{array}$ & $\begin{array}{l}\text { A tanár befolyásolás nélkül } \\
\text { számol be. }\end{array}$ & $\begin{array}{l}\text { Kimaradhatnak részletek (ahol } \\
\text { a tanár bizonytalan volt, nem } \\
\text { mondja el), idö telik el közben. }\end{array}$ \\
\hline $\begin{array}{c}\text { 2.,AA kutató } \\
\text { irányít" }\end{array}$ & $\begin{array}{l}\text { Nem marad ki fontos részlet, } \\
\text { azonnali felidézés. }\end{array}$ & A beszámoló irányított. \\
\hline $\begin{array}{c}\text { 3.,,A tanár } \\
\text { irányít" }\end{array}$ & $\begin{array}{l}\text { A tanár befolyásolás nélkül } \\
\text { számol be, azonnali felidézés. }\end{array}$ & Kimaradhatnak fontos részletek. \\
\hline
\end{tabular}


A fenti hátrányok elkerülése érdekében a kutatók gyakran kombinálják a felvétel megtekintésének módjait, vagyis a kutatási alany állítja meg a felvételt, de amennyiben a kutatás szempontjából lényeges mozzanat maradna ki, a kutató irányított kérdések formájában rákérdez.

\section{Támogatott felidézés módszere roma és nem roma gyerekek társas kapcsolatainak vizsgálatában}

\section{A kutatás célja}

Kutatásunk célja, hogy feltárjuk a roma és nem roma gyerekek interakcióit, valamint a mögöttük meghúzódó gondolatokat, attitüdöket. A kutatás során elsődlegesen arra a kérdésre kerestük a választ, hogy miként látják egymást a roma és nem roma gyerekek, illetve maguk hogyan élik meg és kezelik a felmerülö konfliktusokat. Erre legalkalmasabbnak a támogatott felidézés módszerét találtuk, hiszen fontos volt, hogy a tanórákat rögzíteni tudjuk, hogy a kutatási alanyok külső szemlélöként is láthassák tanórai tevékenységüket, az osztályban betöltött helyüket és szerepüket.

\section{A kutatás körülményei}

Két kb. 1000-1300 lelkes közép-dunántúli település általános iskoláiban egy-egy alsó és egy-egy felső tagozatos osztályban végeztünk vizsgálatot osztályonként két tanulóval, valamint az osztályfőnökökkel. A kutatás során minden osztályban két tanóra felvételére került sor néhány hónap különbséggel, melynek eredményeként összesen 28 támogatott felidézés interjút készítettünk el.

Kutatásunk megkezdésekor feltételeztük, hogy kisiskolás korban a roma és nem roma tanulók közötti interakciók nélkülözik az elöítéleteket, míg serdülőkorban gyakran válik feszültséggel terhessé a roma és nem roma gyerekek közötti társas kapcsolat. A kutatás céljának megfelelő osztályokból egy roma és egy nem roma tanulóval, valamint az osztályfönökkel végeztünk vizsgálatot a támogatott felidézés módszerével. Feltételeztük, hogy az osztályfőnököktől általánosabb képet kaphatunk az osztályközösségröl, a felmerülő konfliktusokról, valamint a kiválasztott tanulók osztályban betöltött szerepéröl, helyéröl.

Mivel kutatásunk célja az volt, hogy iskolai keretek között vizsgáljuk a roma és nem roma tanulók közötti társas kapcsolatot, ugyanakkor jól rögzíthetőek legyenek a tanulók közötti interakciók, a viselkedési problémák, a verbális és non verbális kommunikáció elemei, ezért kötetlenebb tematikájú tanórákon készítettünk felvételt (pl.: testnevelés, technika, osztályfőnöki óra). Hiszen egy erős tanári kontroll alatt tartott tanóra során a tanulók közötti interakciók rögzítésére kevés lehetőség kínálkozott volna. 
A vizsgálatot május végére-június elejére időzítettük, mert a kutatás céljának jobban megfelelt a tanév végi órai munka oldottabb légköre. A tanóra felvétele után azonnal elkészítettük az interjúkat a tanulókkal, majd az osztályfőnökökkel.

\section{Kutatási alanyok kiválasztása}

A kutatási alanyok kiválasztása több szempont figyelembevételével történt. Elsődleges szempont volt, hogy az egyik tanuló a roma, a másik pedig a nem roma közösséget képviselje. Emellett a tanulónak jó kommunikációs készségekkel kellett rendelkeznie, hogy a támogatott felidézés interjú kivitelezhető legyen. Az ilyen módon szükített, lehetséges tanulói csoportból a kutatási alany kiválasztása az osztályfönök segítségével, valamint a bemelegítő óra és az arról készült felvétel viszszanézése közbeni tapasztalatok alapján történt.

\section{A kutatás folyamata és a módszer müködése a kutatásban}

A támogatott felidézés alkalmazásához O’Brien (1993) leírását vettük alapul, aki hat fázisban összegzi a kutatás menetét:

1. kutatási alanyok kiválasztása és felkészítése;

2. videofelvétel elökészítése;

3. videofelvétel;

4. támogatott felidézés interjú;

5. az interjú szövegének feldolgozása;

6. az adatok elemzése.

\section{1. fázis: Kutatási alanyok kiválasztása és felkészítése}

O’Brien felhívja a figyelmet, hogy a kutatás szempontjából fontos, hogy a kiválasztott tanulók képesek legyenek jól kifejteni a gondolataikat, megfelelő időt tudjanak szánni az interjúra, és felkészültek legyenek arra, hogy videofelvételt készítenek róluk az osztályteremben. Körülbelül 15 perces, rövid interjúk alatt ki lehet deríteni a fenti tulajdonságok meglétét. Vagyis mindenképpen szükség van egyfajta előinterjú készítésére. A kutatásunkban mi azzal a módszerrel éltünk, hogy kezdetben tanórai megfigyeléseket végeztünk, majd szünetekben csoportosan beszélgettünk a tanulókkal, végül az osztályfönök javaslatát is kértük és figyelembe vettük ezzel kapcsolatban.

Tuckwell és $O$ 'Brien is jelzi, hogy legalább egy „bemelegíto”” ún. 'dry run' órát kell a tényleges felvétel előtt rögzíteni, hogy a többi tanuló, akik mint interjúalanyok a kutatásban nem vesznek részt, is megszokják a kamera és a kutató jelenlétét. A felvétel után lehetőséget kell biztosítani a tanulóknak és a tanárnak is arra, hogy visszanézhessék magukat, hiszen mindenki elsősorban a fizikai jellemzőire koncentrál, amikor először látja magát filmen, és csak később, amikor ezt már 
megszokta, hangolódik rá a természetes cselekvésekre (Tuckwell, 1980a; Tuckwell, 1980b). A 'dry run' órák felvételeit természetesen később nem használják a kutatásban. Ha a támogatott felidézést hosszabb ideig alkalmazzák, vagy ha jelentős szünetek vannak az alkalmazása közben, akkor a kutatónak ügyelnie kell az alanyok újbóli ráhangolására, szükséges esetén egy újabb „bemelegítő óra” segítségével (Tuckwell, 1980b).

Kutatásunk során mi magunk is megtapasztaltuk a „bemelegítő órák” jelentőségét, hiszen az ilyen felvételeken jól kirajzolódott, hogy az extrovertált tanulók a kamerára koncentráltak elsősorban, és kevés figyelmet fordítottak a tanórai munkára, szívesen „produkálták” magukat a felvételeken, például integettek, izegtek-mozogtak. Az introvertált típusú tanulók pedig sokkal visszahúzódóbbak lettek, például sokkal kevesebbszer néztek a tanárra, tekintetüket inkább az elöttük lévő könyvükre és füzetükre vetették. A bemelegitő órát követően a tanulók és a tanár is megtekinthették a felvételt, melynek során elsődlegesen a külső megjelenésükre, gesztusaikra, hangjukra figyeltek. Ezt követően mindannyian megszokták a kamera és a kutató jelenlétét és tevékenységeik természetessé váltak.

\section{2. fázis: A terem előkészítése a videofelvételre}

A szakirodalomban O'Brien (1993) azt írja le, hogy általában két kamerát állítanak fel az osztályteremben, mivel az egyik a tanárt veszi, és az egyéb eszközöket (pl.: táblát, videót, diákat, írásvetítőt) a másik pedig a tanulókat. Egy mikrofont is elhelyeznek a teremben úgy, hogy mind a tanár mind a kutatási alanyok hangját jól tudják rögzíteni.

Ezzel szemben a kutatás technikai kivitelezéséhez mi egy videokamerát használtunk, mivel a kutatásunk nem a tanári tevékenységre irányult, sokkal inkább a tanulók közötti interakciókra, így kevés hangsúlyt fektettünk a tanár tevékenységének, illetve az egyéb eszközöknek a felvételére. A videokamerát igyekeztünk úgy elhelyezni az osztályteremben, hogy jól rögzíteni tudjuk a tanulók tevékenységét. Sajnos a termek adottságai miatt nem tudtuk megoldani azt, hogy a kamerát teljes mértékben rögzítsük, mivel nem lehetett akkora látószöget biztosítani, hogy minden tanulót egyszerre tudjunk felvenni. Ezért a tanórai történések pontos rögzítése érdekében a kamerát forgatni kellett, de ezt igyekeztük folyamatosan tenni, hogy minden tanuló tevékenységét jól rögzíteni tudjuk. Külön mikrofon elhelyezésére nem volt szükség mivel a kamerába épített mikrofon jól hallhatóan rögzítette az eseményeket.

\section{3. fázis: A videofelvétel}

A szakirodalomban a támogatott felidézéshez felvett órák száma nagyban függ a technikai felszerelés rendelkezésére állásától, a kutatásra szánt időtől és a tanítási/tanulási stratégiák változatosságától. O'Brien szerint a tapasztalat azonban azt mutatja, hogy általában 4 órát vesznek fel 2-3 hetes periódus alatt. 
O’Brien figyelmeztet, hogy a felvétel alatt ügyelni kell arra, hogy a kamera kijelzőjét a tanulók ne láthassák, emellett kerülnünk kell a zoomolást is. Kutatásunk során mi magunk is ügyeltünk e szabályok betartására, a felvétel során a tanulók a kamera kijelzőjét nem láthatták, és zoomolást csak egyetlen egy, kivételes esetben alkalmaztunk, amikor az egyik roma fiú tanórai tevékenysége szembetünő és a kutatás szempontjából fontos volt, ugyanakkor az előtte ülő diák miatt nem volt teljesen tisztán látható. Ebben az egy esetben azért alkalmaztuk, hogy jól tudjuk rögzíteni a fiú tanórai viselkedését.

\section{4. fázis: A támogatott felidézés interjú}

Szivák hangsúlyozza, fontos, hogy az interjú rögtön a felvett óra után elkészíthető legyen. Az interjúalany elött minden esetben világossá kell tenni, hogy a felvétel nézése közben minden olyan helyen, ahol a vizsgálat tárgyát képező kérdésben valamilyen gondolati aktus volt, állítsa meg a filmet és azokat kommentálja (pl. mit érzett akkor). Erre kutatásunkban mi magunk is nagy hangsúlyt fektettünk.

Az interjú elkészítésének irányelveit a szakirodalomban O'Brien írja le a legrészletesebben, melyeket az alábbiakban felsorolásszerüen kívánunk bemutatni saját kutatási tapasztalatainkkal kiegészítve:

- Mindig nyugodt környezetet teremtsünk az interjúhoz egy zárt vagy elkülönített szobában.

Kutatásunk során mindkét iskolában biztosították számunkra ezt a követelményt, így nyugodt környezetben folytathattuk le az interjúkat, néha az igazgatói irodában, néha a könyvtárteremben, máskor pedig a technikai teremben.

- O’Brien leírja, hogy minden alannyal külön kell elkészítenünk az interjút, egymás után, melyek mindegyike 45 percig kell, hogy tartson. Szintén tanácsos követni az 1. ábrán bemutatott elrendezést.

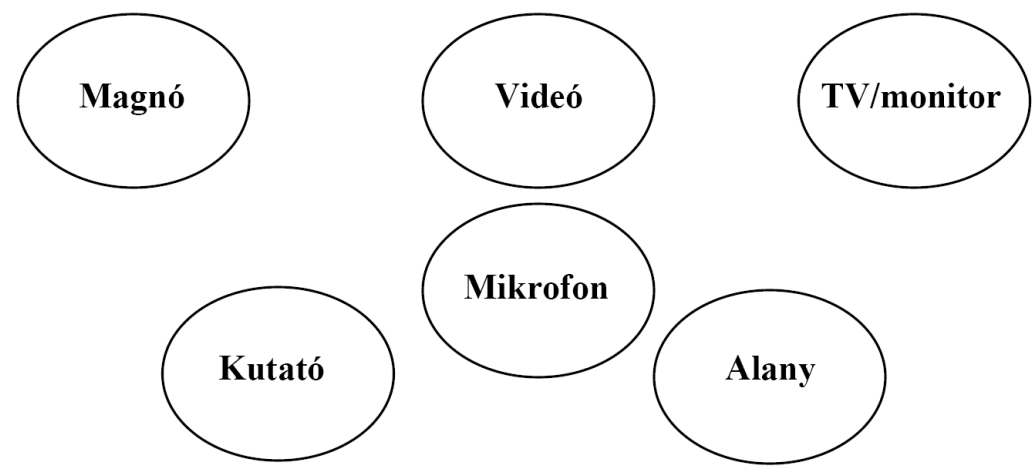

1. ábra: A terem javasolt elrendezése (O’Brien, 1993) 
Kutatásunk során a tanóra felvétele után azonnal elkészítettük az interjúkat a tanulókkal, majd az osztályfőnökökkel, melyek mindegyike legkevesebb 45 percig tartott, de az is előfordult, hogy egy vagy akár másfél órás volt az interjú egy-egy kutatási alannyal. A terem berendezésében a technikai különbözőség okán nem teljesen követtük $O$ 'Brien javaslatait. A felvétel rögzítéséhez diktafont alkalmaztunk, így nem volt szükség külön mikrofonra és magnóra, mivel az interjúalany és a kutató közé elhelyezett diktafonnal jól rögzíthető volt az interjú minden részlete. A videofelvételt hang nélkül játszottuk vissza a kutatási alanyoknak, mivel nagyobb hangsúlyt kívántunk fektetni a non verbális kommunikációra, valamint a tanulók viselkedésére, mint magára a tanórán elhangzottakra. Abban az esetben, ha a verbális kommunikáció is jelentőséggel bírt a kutatás szempontjából, a tanórán elhangzottak is feljegyzésre kerültek, melyet az interjúalanyok aztán véleményeztek.

E tekintetben kutatásunk ugyancsak újszerünek mondható, hiszen a felvétel megtekintésének ilyen jellegủ módját más kutatóknál még nem tapasztaltuk. Ez az új eljárás tette lehetővé számunkra, hogy az interjú alatt a kutatási alanynak nem volt szükséges megállítania a felvételt, hiszen folyamatosan tudta kommentálni az eseményeket, anélkül, hogy a felvétel hanganyaga zavarta volna gondolatmenetét vagy elterelte volna figyelmét. Amennyiben a kutatás során jelentőséggel bírt a verbális kommunikáció anyaga, úgy irányított kérdések formájában külön kértük a kutatási alanyt ezzel kapcsolatos véleményének, gondolatának kifejtésére.

\section{5. fázis: Az interjú szövegének feldolgozása}

A kutatás legnagyobb nehézségét az interjúk szövegének feldolgozása adta, hiszen rendkívül komoly munkát és energiát jelentett a 28 darab, legkevesebb 45 perces támogatott felidézés interjú szövegének rögzítése.

\section{6. fázis: Adatelemzés}

A támogatott felidézés interjúk során olyan harmonikus légkört sikerült teremtenünk, amely hozzásegítette a kutatási alanyokat ahhoz, hogy véleményüket, gondolataikat szabadon kifejtsék. Ennek eredményeként olyan széles spektrumú és olyan mennyiségü adatot kaptunk, amely nem csak kutatásunk, azaz a roma és nem roma gyerekek társas kapcsolatának vizsgálata szempontjából volt érdekes, hanem számos olyan téma szempontjából is, melynek vizsgálata jelen kutatásunknak nem volt célja.

Így tehát az interjúk adatelemzése során igyekeztünk pusztán azokra az információkra koncentrálni, melyek kutatásunk számára relevánsak voltak. De ehelyütt meg kell jegyeznünk azt is, hogy ezzel nem tekintjük lezártnak az interjúk adatelemzését, hiszen még nagyon sok olyan hasznos és hasznosítható adat áll a rendelkezésünkre, melyek egyrészt kutatásunk anyagának bővítéséhez használhatók majd a későbbiekben, másrészt pedig egészen más irányú kutatásokhoz nyújthatnak segítséget. Azaz feltétlenül szükségesnek tartjuk az interjúk ilyen célzattal történő újrafeldolgozását. 
A módszer előnye és az alkalmazás problémái

Természetesen, mint minden kutatási módszernek, a támogatott felidézésnek is megvannak a maga előnyei és hátrányai. O'Brien elönyként jegyzi meg, hogy meglehetősen könnyü használni a támogatott felidézés módszerét és az általa kapott adat is egyaránt változatos és gazdag. Fenti állításával teljes mértékben egyet tudunk érteni a tekintetben, hogy a kapott adatok sokszínúsége jócskán felülmúlta a módszerrel szemben támasztott elvárásainkat. A használhatóságát talán csak technikai igénye nehezíti meg, amely viszont a mai tudásunk mellett nem jelenthet igazi problémát.

Szivák a módszer azon sajátosságát emeli ki, hogy a támogatott felidézés esetében voltaképpen egyszerre külső szemlélőként és belső résztvevőként végzett analízisről van szó. Ez a vizsgált személynek is komoly információt ad saját magáról, így segíti elő a pontosabb önismeretet. Éppen ez volt az a sajátosság, amely miatt a támogatott felidézés alkalmazása mellett döntöttünk, hiszen célunk volt feltérképezni a roma és nem roma gyerekek közötti interakciókat és szembesíteni a kutatási alanyokat azokkal a sokszor tudatalatti cselekvéseikkel, melyeket a mindennapi kommunikáció és együttlét során egymással szemben alkalmaznak.

Szivák a módszer egyik problémájaként emeli ki, hogy számos tényező befolyásolja azt, hogy a tanulók/tanárok meddig és milyen mértékben képesek visszaemlékezni, beszélni gondolataikról. A tanulók/tanárok bizonytalansága, vagy magabiztossága befolyásolhatja a felidézést. Minden személy másként érzékeli azokat a szituációkat, melyekben résztvevőként szerepel. Több tanár számára például az órájával való szembesülés feszültséget eredményezhet. Ennek a fesztültségnek az oka, hogy az óra visszajátszása során újra megélik az eseményeket, de már másfajta perspektívában, mely zavart okozhat, különösen, ha bizonyos szituációkban már másképp döntenének. Ezt a feszültséget ítéletmentes légkör biztosításával lehet oldani. Ezen kívül - figyelmeztet Szivák -, tisztában kell lennünk azzal is, hogy a tanárokban erős késztetés él, hogy megfeleljenek az elvárásoknak.

Ezt a fajta problémát szerencsére nem érzékeltük kutatásunk során, amely annak köszönhető, hogy körültekintően jártunk el az iskolák kiválasztásakor. Így olyan iskolákban végeztük a kutatást, ahol baráti, ismerősi szálak révén teljes mértékben együtt kívántak velünk müködni és kutatásunkat elösegíteni. Nem kellett tehát szembesülnünk azzal a problémával, hogy nehézségeiket, olykor tehetetlenségüket el akarták volna leplezni. Ezzel utat engedtek annak, hogy kutatásunkkal fel tudjuk tárni a problémákat és ezzel lehetőséget tudjunk adni arra, hogy a megoldás felé induljunk el.

Gondot jelentett azonban, hogy az egyik kutatási alany az interjú készítése során túlzottan feszélyezve érezte magát, annak ellenére, hogy a korábbi tapasztalatok azt mutatták, hogy a kutatási célnak megfelelö, kommunikatív tanulóról van szó. Ebben az esetben az interjút több kérdés feltevésével kellett irányítanunk. En- 
nek ellentettje volt tapasztalható két tanulónál, akik kevés figyelmet fordítottak a tanórai felvételre, sokkal inkább saját élményeikről, családi körülményeikről és a számukra fontos történésekről kívántak beszélni. Ezekben az esetekben is kérdésekkel próbáltuk ráirányítani a figyelmet a kutatás szempontjából fontos felvétel részletekre.

\section{A kutatás jelentösége}

A kutatás mind témájában, mind a vizsgálathoz alkalmazott módszer tekintetében hozott újat. Ugyan sok kutatás zajlott és zajlik a roma gyerekek oktatásával kapcsolatban, azonban ez idáig nem irányult kellő figyelem arra, hogy a roma és nem roma gyerekek hogyan észlelik egymást, társas kapcsolataik milyen módon alakulnak, és ezeket mennyire befolyásolják a jelenlegi társadalmi és globális szintü változások, valamint, hogy hogyan látják és milyen problémakezelő stratégiákat, milyen hatékonysággal alkalmaznak a pedagógusok.

A támogatott felidézés módszerének fenti témában történő alkalmazása szintén a kutatás újszerüségét jelenti. A módszer segítségével feltárhatóvá váltak a roma és nem roma tanulók gondolatai, attitüdjei. Az interjú technikán módszerünk oly módon mutat túl, hogy a kutatási alanyok nem elsődlegesen a kutató által feltett kérdések segítségével nyilatkoznak a témáról, hanem önállóan, a felvétel megtekintésekor felmerült gondolataikról, érzéseikről szólnak, így szabadon szárnyalhatnak a gondolataik akár más kapcsolódó témák irányába is. Például több esetben nyertünk betekintést a roma családok életébe, hiszen a roma tanulók közül többen szívesen beszéltek a mindennapjaikról, a családi hagyományaikról és szokásaikról. Emellett megismerhettünk gondjaikat, konfliktuskezelési technikáikat és egyben vérmérsékletüket is.

Ugyanakkor a támogatott felidézés interjú során a kutatónak lehetősége van kérdések feltevésével a tanulók gondolatainak feltárására azon témákban is, melyekről önmaguktól nem nyilatkoztak volna. Ezen kívül a felvétel lehetőséget biztosít a kutatási alanyoknak, arra, hogy magukat más szemszögből láthassák, hiszen mintegy kívülállóként elemezhetik saját interakcióikat, viselkedésüket is.

\section{A kutatás néhány eredménye}

Kutatásunkban feltételeztük, hogy kisiskolás korban a roma és nem roma tanulók közötti interakciók nélkülözik az elöítéleteket, míg serdülökorban gyakran válik feszültséggel terhessé a roma és nem roma gyerekek közötti társas kapcsolat.

Erre egyértelmü igazolást vagy cáfolatot ugyan nem kaptunk, azonban a szociometriai, illetve a támogatott felidézés vizsgálatok során az látszott körvonalazódni, hogy kisiskolás korban nem jelenik meg az elöítélet a tanulók interakcióiban, társas kapcsolataiban, az ellentétek inkább az egyes tanulók személyiségbeli jegyeiböl adódnak. A serdülőknél, annak ellenére, hogy kutatásunk során súlyos konfliktusokkal is találkoztunk, még sem jelenthetjük ki egyértelmüen, hogy azok a kölcsö- 
nös előítéletekben gyökereztek volna. Az azonban tisztán látszik, hogy a szülöi háttér sokkal nagyobb elöítélettel bír, mint maguk a tanulók. Ez az igazgatókkal készült mélyinterjúk, valamint az osztályfőnökökkel végzett támogatott felidézés vizsgálat során vált egyértelművé. Sajnos sok esetben ez a szülői elöítélet az, amely rávetítődik a gyermekek társas kapcsolatára, és mintegy újratermeli az elöítéleteket.

Továbbá az is kirajzolódott, hogy a roma tanulók serdülö korukban egyre inkább kiszakadni látszanak az oktatási rendszerből, egyre inkább elsőbbséget élveznek a családi események, a pénzkereset vagy éppen a családalapítás a tanulással szemben. Ez egyben azt is jelzi, hogy a vizsgált közösségekben a tanulás prioritása rendkívül alacsony.

Kutatásunkban feltételeztük azt is, hogy új iskolába kerülve a nem roma tanulókat sokkal könnyebben és hamarabb fogadja be és el környezetük, mint roma társaikat.

A vizsgált osztályok mindegyikében ez a jelenség észlelhető volt, legszembetünőbben az alsó tagozatban. Mivel kutatásunk keretében csak kis mintán tudtuk fenti hipotézisünk helytállóságát vizsgálni, így azt nem tekinthetjük teljességgel igazoltnak. Azonban mindenképpen felhívja a figyelmet a jelenségre, melynek vizsgálata szükségszerü lenne egy másik kutatás keretében.

Mivel a nemzetközi szakirodalomban Corrigan (1998) már eredményesen alkalmazta a tanár-diák interakciók mögött meghúzódó kulturális elöítéletek kutatásakor a támogatott felidézés módszerét, ezért feltételeztük, hogy a módszer jól alkalmazható más hasonló témakörü kutatásokban, így a roma és nem roma gyerekek társas kapcsolatának vizsgálatában is. Fenti hipotézisünk helytállósága bizonyítást nyert, hiszen a támogatott felidézés módszerével sok olyan információhoz juthattunk, melyre egyébként nem lett volna lehetőségünk. Természetesen a módszer hasonló témakörü kutatásban való alkalmazásakor figyelembe kell venni és lehetőség szerint ki kell küszöbölni azokat a problémákat, nehézségeket, melyekröl $A$ módszer elönye és az alkalmazás problémái c. alfejezetben mi magunk is szólunk.

\section{Összefoglalás}

A támogatott felidézés módszerét - mely ugyan sok rokonságot mutat az interjútechnikával, azonban mégis számos ponton túlmutat azon -, régóta eredményesen alkalmazzák változatos pedagógiai kutatásokban. Jelen tanulmányunkban célul tüztük ki a támogatott felidézés sokrétủ alkalmazási lehetőségeinek bemutatását konkrét kutatásokon keresztül, melyekből úgy véljük, egyértelmüen kitünik, hogy a módszer körültekintő alkalmazása során milyen gazdag, változatos információt szolgáltat. A módszer bemutatását követően a föbb kutatókat, kutatásokat törekedtünk csokorba szedni - természetesen a teljesség igénye nélkül -, majd igyekeztünk az alkalmazás menetét gyakorlati tanácsokkal bővítetten, részletesen leírni. Mindazonáltal tanulmányunkban nem kívántuk elhallgatni a módszer alkalmazásának nehézségeit, korlátait sem, hiszen csak így kaphatunk teljes képet a támogatott felidézésröl. 
Kutatásunk során alkalmazva magunk is meggyőződtünk arról, hogy a támogatott felidézés módszere nagyon sok, a kutatás szempontjából rendkívül fontos adatot szolgáltat, ugyanakkor pontosan tudnunk kell a módszer határait is. Ezért is fordítottunk hangsúlyt jelen tanulmányunkban arra, hogy a módszer alkalmazásának nehézségeiről, hátrányairól is szóljunk saját kutatásunk kapcsán.

Természetesen minden kutatót szeretnénk bátorítani a támogatott felidézés módszerének alkalmazására, hiszen számos olyan információhoz juttathatja a kutatót, melyet más módszer segítségével nem tárhatott volna fel.

\section{Irodalom}

Clark, C. M., Peterson, P. (1986): Teachers' thought processes. In: D. C. Berliner, R. C. Calfee (Eds.): Handbook of research on teaching. New York, Macmillan

Falus Iván (1985): A videotechnika alkalmazása a tanári döntéshozatal kutatásában. In: Poór Ferenc (szerk.): Képmagnetofon alkalmazása a képzésben és továbbképzésben V. Országos Oktatástechnikai Központ, Veszprém, 39-55.

Kotschy Beáta (1985): A tanítási tervektől való eltérés okainak vizsgálata. In: Poór Ferenc (szerk.): Képmagnetofon alkalmazása a képzésben és továbbképzésben $V$. Országos Oktatástechnikai Központ, Veszprém, 56-61.

O'Brien, J. (1993): Action research through stimulated recall. Research in Science Education, 23, 214-221.

Powell (1992)

Sántha Kálmán (2004): A pedagógusok reflektív gondolkodásának vizsgálata. Pedagógusképzés, 2, 27-44.

Sántha Kálmán (2007): Kvalitatív módszerek alkalmazása a reflektív gondolkodás feltárásában. In: Falus Iván (szerk.): A tanárrá válás folyamata. Gondolat Kiadó, Budapest, $177-243$.

Szivák Judit (2002): A pedagógusok gondolkodásának kutatási módszerei. Kutatás-módszertani Kiskönyvtár, Pedagógus Könyvek, Müszaki Kiadó, Budapest.

Szokolszky Ágnes (1985): A pedagógus tanórai percepciójának vizsgálati lehetőségei videomagnó felhasználásával. In: Poór Ferenc (szerk.): Képmagnetofon alkalmazása a képzésben és továbbképzésben $V$. Országos Oktatástechnikai Központ, Veszprém, 62-85.

Tuckwell, N. B. (1980a): Content Analysis of Stimulated Recall Protocols. Centre for Research in Teaching, Faculty of Education, University of Alberta, Alberta.

Tuckwell, N. B. (1980b): Stimulated Recall: Theoretical Perspectives and Practical and Technical Consideration. Centre for Research in Teaching, Faculty of Education, University of Alberta, Alberta.

Westermann, D. A. (1991): Expert and Novice Teacher Decision Making. Journal of Teacher Education, 42, 292-305. 